to such people? They are out of harmony with the existing order and they refuse to submit to the orders of the powers that be.

We are asked to suggest the appropriate treatment for these offenders. Well, we may have no adequate remedy to propose. Then comes the accusation that destructive criticism is practically useless unless accompanied by remedial sug. gestions. We claim, however, the right to insist that if men or women are sick, mentally, morally or physically, the remedy applied in each case should be such as to cure the patient of his malady. We do not profess to know the best method of curing dipsomaniacs, monomaniacs or polymaniacs. We merely ask that the remedy shall be adapted to the condition of the patient and we have a right to expect a treatment which will result favorably to the patient. Something is wrong either with the diagnosis or with the remedy. Why not try some other antidote or specific? Is the pharmacopeia of the science of penology confined to the thumb-screw methods of the Middle Ages?

What is the remedy? Neither ipecac nor the whipping-post. Education, Education, and again Education. The prison should be transformed into a seminary and the education should begin in time to make the prison an empty tenement.

\title{
SOME EFFECTS OF PRISONER IDLENESS
}

\section{By Rev. Zed Hetzel Copp, D.D.}

Former Chaplain, Eastern Penitentiary

The most noticeable and immediate trunk-line effects of prisoner idleness are physical, mental and moral degeneracy.

1. Physical Degeneracy is the result of bodily inaction.

The prisoner as a citizen had been accustomed to come and go when he pleased, exercising body and limb without restraint. He filled his lungs with the pure air of heaven and sought action and sunshine whenever he felt like it. Thus he constantly gave his body those elements which are necessary to its well being, and his appetite and labor, the latter such as it was, stored him with an electrical energy which edged him for perilous places.

Now he is confined in a living coffin on an average of twenty-two hours a day, in which he gets little fresh air and less sunshine. He eats not to labor, but to live in as good condition as possible to endure his confinement.

The first effect of this change from the free life of the citizen to that of the idle prisoner is a burning fever involving every cell of the body in a vigorous battle against inaction. Brainstorms sweep the mind and curses the lips. The man is undergoing the initial stage of physical degeneracy. These periods of physical protest reoccur with lessening force and frequency until structural degeneracy has produced contented idleness, slothfulness, sleepiness, biliousness, disease culture, tubercular taint and lust culture.

2. Mental Degeneracy is the result of bodily inaction and thought isolation.

The prisoner as a citizen had been accustomed to think with the current of world thought in free and diversified intercourse with others, had enjoyed daily newspapers, church privileges and amusements. He planned his life action 
and very often he had to invent methods of procedure which, if they had been lawful, would have brought him wealth and honor.

Now he is marooned in a dead sea of ruined reputations where there is a constant back-wash of recited criminal escapades, real and imaginary, and also a deadly and irresistible under-current of formative criminal life which sweeps him into the so-called criminal class. Thought isolation is made more complete by the adverse attitude of the keeper towards his letters and visits.

He had hoped for employment to psychologically shorten his term. But after frequent disappointments, he grew bitter and resentful and finally became incipiently rebellious against all prison discipline. Now he is content to eat and sleep like the gormandized animal, exchange immoral gossip, and he has become acutely temperamental and borders on melancholy and insanity.

3. Moral Degeneracy is the result of physical degeneracy plus mental degeneracy minus God.

The prisoner as a citizen has been physically and mentally alive to an everwidening and changing circle of thought and action. These benefits produce of themselves a kind of rugged morality, which may or may not have measured up to the Tables of Stone. Now however dwelling in a living coffin, in a dead sea of ruined reputations, marooned from the energizing thought of the world, he is both cataleptic and amnesic. His moral perceptions, which have never been very clear and distinct, are now blotted out in a riot of Stygian prison ethics, and in a mental delirium he commits moral suicide. Nothing is wrong now except that which is discovered and punished. All else is right regardless of any moral standard.

4. The total result is a degenerate of the most dangerous type.

From the time society discovers that one of its members has been caught violating the law until general degeneracy takes place, the treatment of the offender is such as to necessarily produce the result. From arrest to ultimate liberation, the whole process is de-Christianizing, de-civilizing and de-humanizing. The arrest, the examination, the trial, the sentence, the transportation to prison and the treatment in prison all tend to transform Dr. Jekyll into Mr. Hyde. The ironic tragedy is that this same Hyde will return again to society and prey upon and terrorize its members, a bitter and costly retributive justice for the methods and care of the socially sick.

The State, in defense of law and order and on behalf of its law-abiding members, should treat its erring sons and daughters after the manner of the Prodigal's father. Let justice and proper punishment be administered with one object in mind - the reclamation of the individual as a good citizen. This would require expert, intelligent, considerate and spiritual care, which should continue without fixed period as Iong as the distemper lasts. The physically and mentally sick are so treated, and why should we differ with the socially sick?

\section{VALUE OF PROBATION \\ By Rev. Russell H. Conwell}

From an Address Delivered before the Municipal Court

I come to you weak from hard work and the effects of almost four score years, to talk to you in the freest and frankest manner concerning the church's 